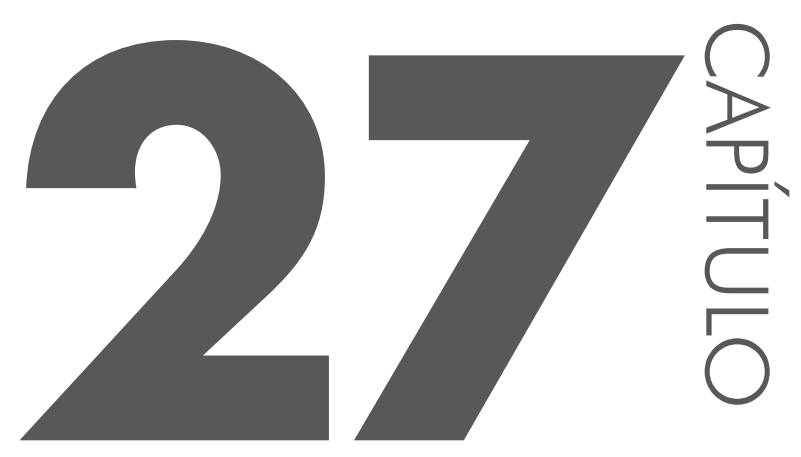

\title{
Notas sobre o ocultamento do associativismo negro na cidade de Laguna, antes e depois da abolição
}

\section{Thiago J. Sayão}

Pós-doutorando no Programa de Pós-Graduação em História (UFSC)

A palestra abordou o processo histórico de ocultamento do associativismo negro na cidade de Laguna, a partir da problematização do silêncio em torno da Irmandade de Nossa Senhora do Rosário (dos Pretos), e dos discursos e práticas de uma nova associação no pós-abolição: a Sociedade Recreativa União Operária (SRUO). Foram acionados os conceitos de "discurso público", de James Scott, e "política de transfiguração", de Paul Gilroy, para responder a seguinte questão: como ler uma associação recreativa denominada Operária, fundada por afrodescendentes, que não assumiram publicamente uma identificação étnico-racial? Entendemos o movimento de apagamento da Irmandade do Rosário e o aparecimento da Operária como o resultado do (re)ordenamento dos afrodescendentes, dentro de um contexto republicano de luta por cidadania.

O objetivo da conferência foi refletir sobre uma identificação racial velada aos sócios da União Operária. Para isso, remetemo-nos à análise nominal dos sócios da Operária e da Irmandade do Rosário. Em uma comparação da relação de nomes dos associados nos dois grupos, encontramos pessoas que mantinham vínculos com ambos. Dentre os sócios da Operária que também eram irmãos do Rosário, estavam: Adolpho Campos, Antão Veríssimo, Antônio Felisberto da Rosa, Bonifácio Deoclesio Gil, Bonifácio Jesuíno Alves, João Augusto de Carvalho, José Alano de Bittencourt, José Antônio de Oliveira, Lucidonio Sypriano e Pedro Jerônimo do Nascimento. 
Foi possível observar que a sede da SRUO era um lugar de sociabilidade, mas também espaço de negociação e fabricação de laços identitários. A cortesia dos sócios do clube em relação aos seus convidados ilustres (párocos, políticos, intelectuais, sindicalistas etc.) pode ser interpretada como uma estratégia de legitimação da própria sociedade e de consolidação da influência do grupo de operários e afrodescendentes na sociedade local. Desse modo, ao invés de considerarmos o comportamento dos sócios da Operária como subserviente, tendo em vista a relação que mantinham com os brancos ilustres da cidade, compreendemo-lo como exercício de infrapolítica: política cotidiana que procura evitar um confronto direto com os detentores do poder político, religioso e econômico. A afirmação de uma identidade racial para a Operária poderia gerar um choque entre grupos sociais e étnico-raciais distintos, inviabilizando, assim, a própria existência da agremiação. $\mathrm{O}$ que muitos interpretariam como branqueamento é entendido, então, como estratégia de resistência.

Nesse sentido, quando a agremiação reproduz práticas e cerimoniais aceitos em um contexto social e cultural específico, isso significa que estava se branqueando enquanto "estratégia para sofrer menos discriminação e ser, talvez, mais aceita" (HOFBAUER, 2005, p. 408). O branqueamento é entendido aqui como um ideário que "abre espectro de negociação, de maneira que qualquer definição de cor/raça reflete, de certo modo, o contexto das relações de poder em que ocorre" (SCOTT, 2000, p. 24-25). ${ }^{134} \mathrm{O}$ ocultamento da identidade racial no discurso público não seria, portanto, o apagamento da herança africana, mas o posicionamento tático de inserção social dos afrodescendentes no pós-abolição. Será que havia, na primeira metade do século XX, na cidade de Laguna, condição real para marcar posição social por meio da afirmação da ascendência africana?

Para entender os fatores que explicam o silêncio da raça no discurso públi$\operatorname{co}^{135}$ da Operária, é preciso considerar o contexto histórico e geográfico, geral e local, de nascimento e desenvolvimento dessa associação. No campo das ideias, havia, nos anos 1900, a circulação de uma produção discursiva em torno da construção de uma identidade nacional, que buscava anular as diferenças étnico-culturais, ao mesmo tempo em que reforçava, sob a ideologia do branqueamento, a valorização da raça e da cultura dos colonizadores portugueses e imigrantes europeus no sul do Brasil. Outra questão importante, no contexto posterior à abo-

134 Segundo Andreas Hofbauer: “A ideologia do branqueamento atua no sentido de dividir aqueles que poderiam se organizar em torno de uma reivindicação comum e faz com que as pessoas procurem se apresentar no cotidiano o mais ‘brancas' possível”. Ibidem, p. 409.

135 Sobre a noção de discurso público como "uma descrição abreviada das relações explícitas entre os subordinados e os detentores do poder", que envolve o "manejo das aparências e das regras de poder", ver: SCOTT (2000, p. 24-25). 
lição, está relacionada com a disciplinarização dos trabalhadores, que mobilizou jornais e polícia em um amplo combate à "vadiagem". As sociedades recreativas e esportivas se apresentavam, nesse período, como solução ao problema da indisciplina e da vagabundagem no espaço urbano. A SRUO também corroboraria para promover a sociabilidade e a educação dos trabalhadores afrodescendentes. Havia, na cultura da SRUO, inclusive, a intenção de resguardar ações e dizeres, possivelmente com o intuito de preservar a imagem de idoneidade aos seus associados. Lemos nos estatutos que, entre os deveres dos sócios, estava: "guardar toda reserva e não divulgar qualquer ocorrência e incidentes desagradáveis ou quaisquer outros fatos que porventura se passarem no recinto da sociedade". ${ }^{136}$

Ser sócio da Operária implicava, também, participar da vida pública e exercer a cidadania no contexto de positivação do trabalho. Associando-se na Operária, o sujeito poderia, por meio do exercício de determinada profissão e da aquisição de conhecimentos (cultura), passar a reivindicar uma condição social superior. O vínculo de classe a partir de uma identidade operária, por seu turno, poderia agir no combate ao estigma da descendência africana relacionada com a escravidão. Nossa hipótese é que a positivação do grupo afrodescendente da SRUO não se deu em função da afirmação da raça e, sim, por valores atribuídos à cultura compartilhada e aceita pela comunidade local, como civilidade, religiosidade, educação e trabalho, o que explica, de certa maneira, o silêncio a respeito de uma identidade racial.

Podemos dizer que a associação União Operária manteve ocultada a identidade racial de seus sócios, ao menos a dos mais influentes, e, ao mesmo tempo, um aspecto importante de sua própria identidade coletiva. Entendemos que o ocultamento da identidade racial fez parte das estratégias políticas cotidianas da sociedade e das relações que os associados estabeleceram com cidade. Um exemplo do sucesso das negociações e táticas micropolíticas, que envolveu o silêncio da identidade étnico-racial, foi a aquisição da sede da associação em local privilegiado da cidade. A compra, em 1922, do imponente edifício em estilo eclético situado na Rua Santo Antônio, esquina com a Rua Tenente Bessa -, foi a garantia de um território negro para as reuniões regimentais, comemorações cívicas, bailes carnavalescos, jogatinas e buffets; um espaço mais seguro para as performances políticas e culturais dos afro-lagunenses.

Portanto, o fim do Rosário, pensado pelo prisma da transfiguração associativa, resiste à versão do desaparecimento da comunidade negra e fortalece uma interpretação baseada nas estratégias de exercício de cidadania em um mundo urbano moderno permeado pelo racismo. A política de transfiguração, salientada 
por Paul Gilroy, nos serve para pensar as performances dos afrodescendentes de Laguna em uma associação operária, uma vez que aponta a formação de uma "comunidade de necessidades e solidariedade" (GILROY, 2012, p. 96), em espaço e tempo definidos. Mesmo que a Operária não tenha reivindicado, em seus documentos, uma identidade étnico-racial, compreendemos que o espírito associativo do Rosário ganhou novo corpo na SRUO, uma instituição mais condizente com o ideal republicano positivista, de civilidade e progresso.

\section{Referências}

GILROY, P. O Atlântico negro: modernidade e dupla consciência. 2. ed. São Paulo: Editora 34; Rio de Janeiro: Universidade Cândido Mendes/Centro de estudos Afro-Asiáticos, 2012.

HOFBAUER, A. Uma história do branqueamento ou o negro em questão. São Paulo: Ed. da Unesp, 2005.

SCOTT, J. C. Los dominados y el arte de la resistencia: discursos ocultos. Ciudad de México: Ediciones Era, 2000. 